\title{
Energi Matahari dan Rumah Sederhana pada Rumah Terencana
}

\author{
Oleh : Sugini
}

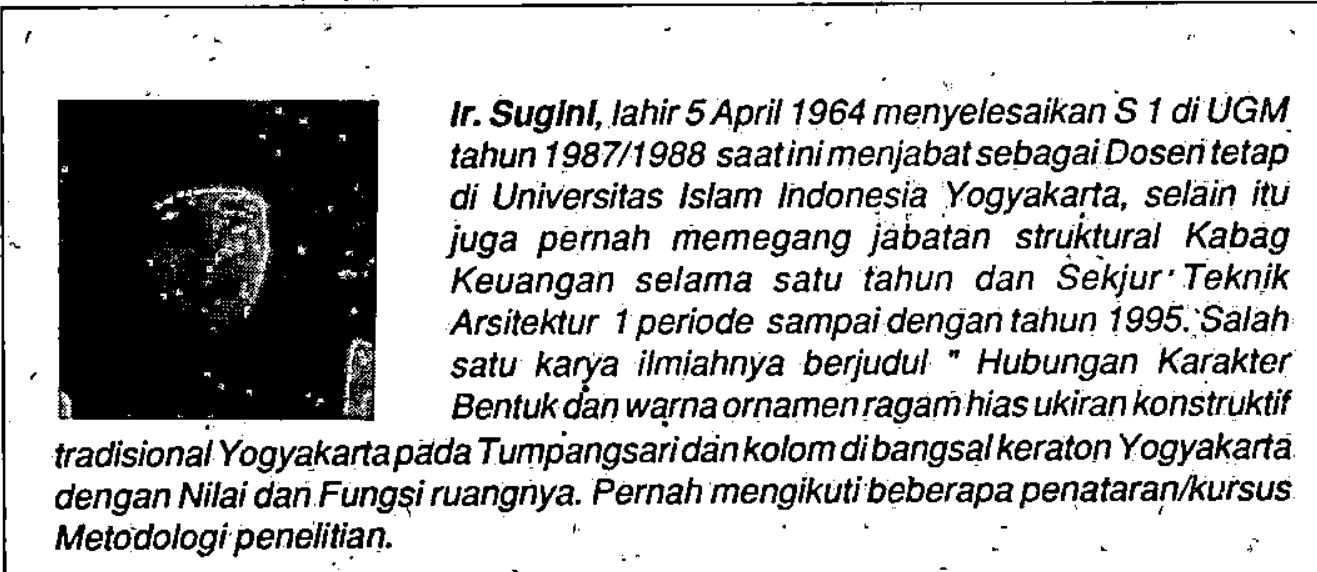

\section{Abstrak}

Perumahan sederhana adalah bagian dari kelas perumahan yang memegang prosentasi besar yang harus diadakan. Usaha penekanan biaya menyebabkan rumah kelas ini sangat tergantung daripengkondisianruang untuk mencapaikinerjafisiologis secara alamiah. Permasalahanpenghawaan, pencahayaan. yang menentukan kinerja fisiologis bertindak dari energi matahari. Sehingga perlu dan menarik untuk membicarakan keduanya. Pada pembahasan ini perumahan sederhana dibatasi päda perumahan sederhana pada kompleks perumahanterencana.Daribahasandapat disimpulkan secara umum bahwa perumahan terencana sederhana dalam mensikapi energi matahari selain melalui disain makro dan mikro yang tepat, juga. tergantung keberadaain sistem manajemen pengendalian pengembangan rumah yang terarah.

\section{Latar Belakang}

Bangunan rumah. adalah jenis bangunan yang secara kuantitas memegang prosentasi yang tinggi keberadaannya dalam komposisi bangunan yang: ada. Dari bangunan rumah dengan berbagai kelas berdasarkan tinjauan ekonomi, maka bangunan sederhana merupakan kebutuhan yang besar_dibanding kelas yang lain.

Rumah sederhana sebagaimana 
bangunan Arsitektur yang lain mempunyai beberapa faktor pertimbangan. Antara lain adalah pertimbangan fungsional. Dalam pertimbangan fungsional antara lain menyangkutaspek tuntutan fisiologis dalam batasan keamanan, keselamatan, kesehatan dan kenyamanan (Siswono Yudohusodo dkk, 1991).

Kenyamanan fisiologis akan menyangkut masalah Pencahayaan, penghawaan, dimana penghawaan terwujud dari hasil gabungan dari kondisi :

1. Temperatur/suhu

2. Kelembaban

3. Gerakan udara

Tiga hal tersebut bermuara dari kondisi energi matahari.

Sehingga perlú dan menarik untuk membicarakan pemanfaatan dan pengendalian energi matahari dalam perancangan rumah sederhana yang diorientasikan pada kebutuhan fisik penghuni.

\section{Energi Matahari (Tenaga Surya)}

Edward Mazriạ dalam bukunya berjudul The Passive Solar Energy Book, 1979, mendefinisikan: Solar energi yang selanjutnya disebut energi matahari adalah radiasi elektromagnetik frekuensi tinggi yang terwujud dari energi yang diakibatkan oleh fusi thermonuklir di pusat matahari.

Dari seluruh radiasi yang diterima oleh bumi (termasuk atmosfir), tiga puluh lima persen akan dipantulkan kembali ke angkasa, dimana penentuan pencapaian radiasi ke bumi akan tergantung dari :

1. Komposisi atmosfir, yang sangat tergantung oleh:
a. Kadar uap air
b. $\mathrm{CO} 2$

\section{c. Ozon}

2. Ketebalan atmosfir yang harus ditembus.

Karena bumi bulatmaka akan tergantung daru waktu dalam hari, dan hari di dalam bulan, serta tergantung bulan dalam tahunnyá.

Gambar 1 : Kedudukan Bumi terhadap matahari akan menentukan ketebalan atmosfir yang berbeda pada bulan yang berbeda.

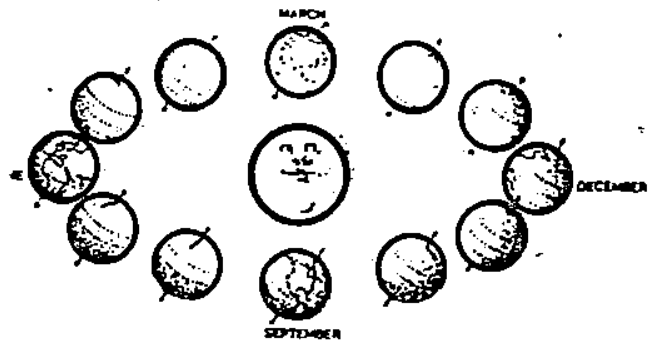

Sumber : Edward Mazria, 1979

Gambar 2 : Rotasi Bumi akan membedakan kondisi atmosfir bumi pada tiap jamnya

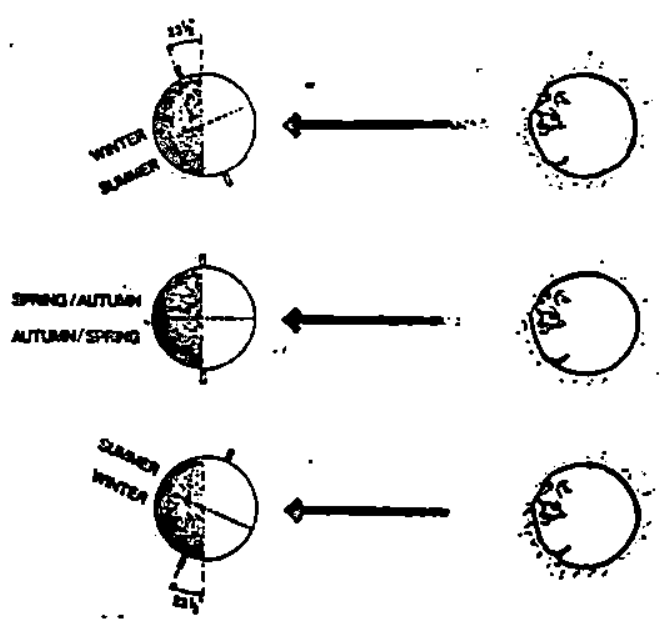

Gb II-5. Kemiringan menimbulkan musinn Sumber: Edward Mazria, 1979.

\section{A. Intensitas Energi Matahari di Permukaan \\ Intensitas energi matahari yang}


mengenai bangunan akan juga tergantung kedudukan bangunan tersebut di permukaan, dimana intensitas energi matahari yang diterima permukaan akan tergantung :

1. Sudut datang sinar matahari terhadap titik di permukaan

Semakin dekat dengan posisi tegak lurus, maka semakin besar intensitasnya. Untuk lebih terinci dapat dilihat dalam tabel sebagai berikut :

Tabel 1 : Prosentasi Radiasi matahari yang mengenai permukaan pada sudut tertentu

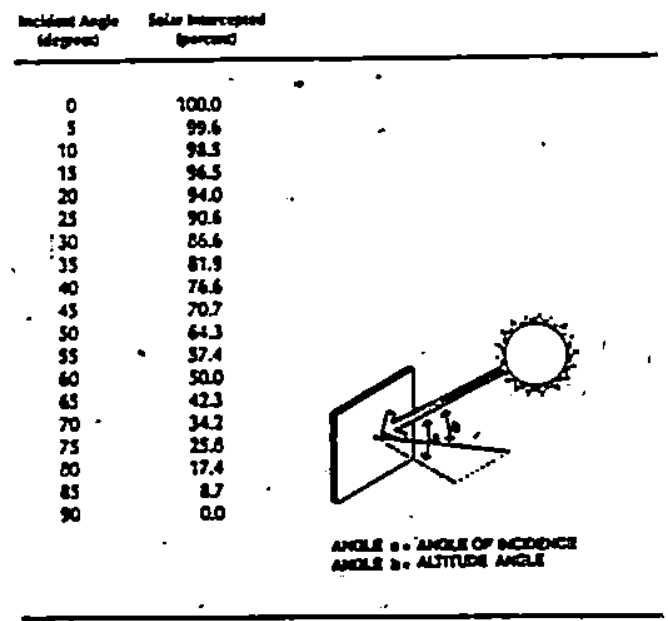

Sumber : Edward Marria, 1979.

2. Jumlah pancaran yang diterima. Dimana pancaran yang diterima tidak hanya berupa sinar langsung, tetapi juga sinar diffus dari sinar refleksi.

Dalam kondisi umum maka dari pancaran yang ada, lima puluh persennya sebenamya dari sinar diffus dan sinar tidak langsung lainnya mencapai seratus persen dari sinar yang diterima.

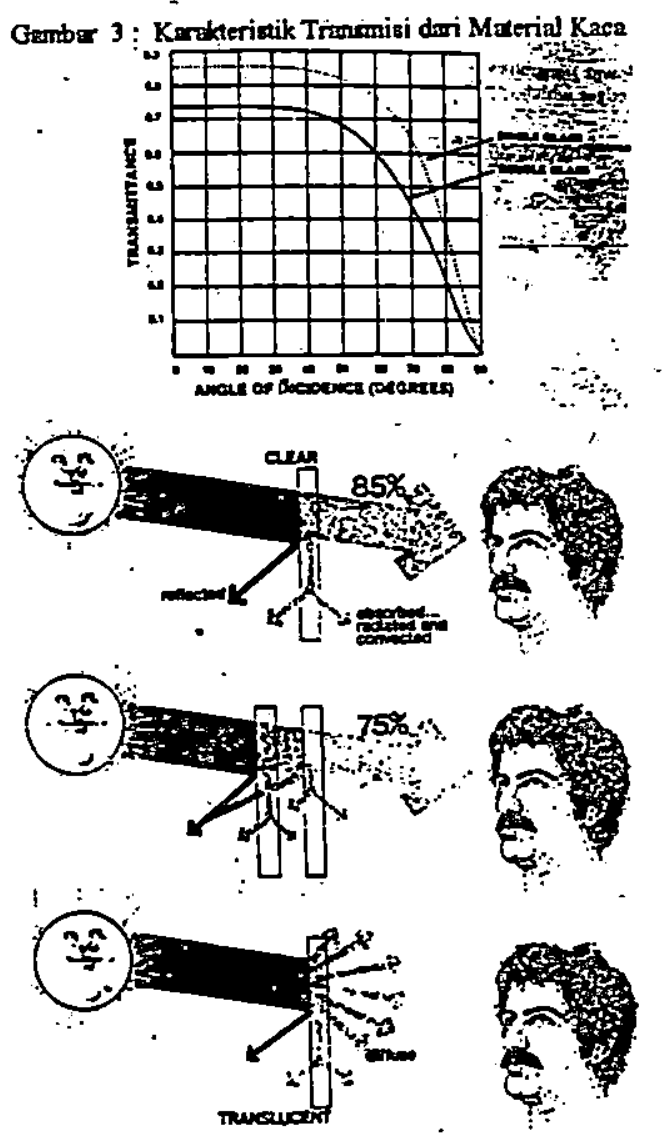

Sumber : Edwerd Mroriz, 1979:

\section{B. Refleksi, Transmisi dan-Absorbsi}

Bagaimana bangunan dalam hal ini rumah sederhana dalam mensikapi energi matahari akan melihat besamya energi yang sampai pada ruang di dalam bangunan. Besamya energi yang akan sampai dalam ruang dalam bangunan tergantung perlakuan bahan/material terhadap energi yang jatuh pada bangunan. Untuk mengetahui bagaimana perlakuan bahan/ material terhadap energi matahari maka haruslah dimengerti tentang Refleksi, Transmisi dan Absorbsi.

Sebagaimana diketahui radiasi sinar 
matahari yang mengenai permukaan akan mengalami proses :

1. Dipantulkan

2. Diteruskan

3. Diserap

Apakah seberkas sinar akan dipantulkan, diteruskan atau diserap akan tergantung dari sifat material. Besamya prosentasi sinar yang diserap, diteruskan atau dipantulkan akan tergantung dari :

1. Besamya sudut jatuh sinar terhadap bidang

2. Jenis material

3. Tekstur permukaan dari material

4. Wama

Gambar 4 : Kualitas permukaan bahan menentukan Refleksi yang terjadi.

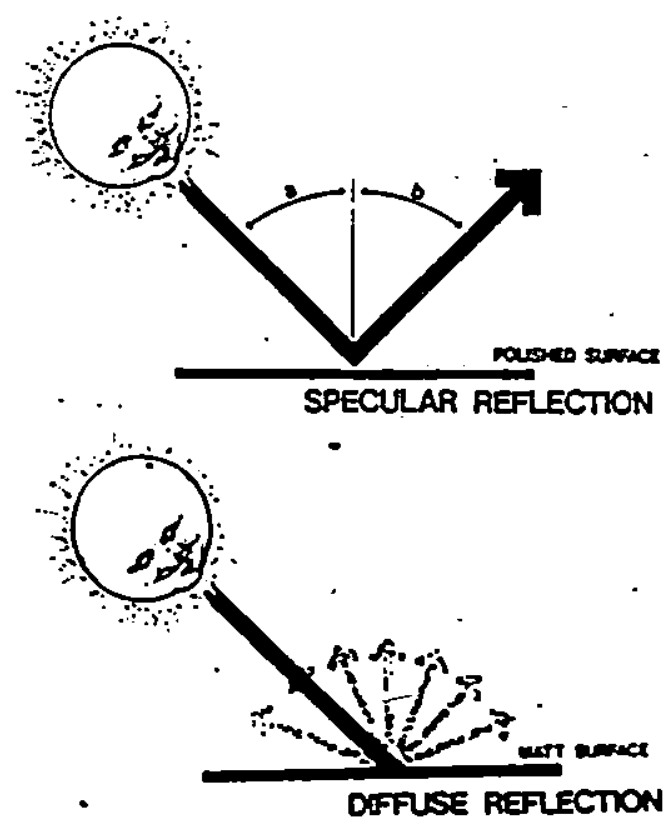

Sumber : Edward Marria, 1979.

Menurut George Lippsmeier, 1980 , intensitas cahaya matahari dan pantulan cahaya matahari yang kuat merupakan gejala di daerah iklim tropis. Di mana hal tersebut bisa menimbulkan silau. Untuk daerah iklim tropis basah, silau yang dialaminya berasal dari langit. Sedangkan untuk daerah iklim tropis kering, silau yang dialaminya adalah silau dari tanah. Dengan demikian penanggulangan masalah silau yang ada di daerah iklim tropis, tentunya hanus disesuaikan. Untuk dapat mengurangi efek silau dapat dilakukan berbagai cara antara lain :

1. Memberi efek bayangan

2. Menutupi bidang pantul dengan material yang sesuai.

Untuk lebih jelasnya berikut ini disajikan tabel tentang nilai pemantulan dan penyerapan dari berbagai material.

Tabel 2:

Nilai Pantul dan Nilai Serab berbagai bahan dengan berbagai kondisi terhadap sinar

\begin{tabular}{|c|c|c|c|c|}
\hline \multicolumn{2}{|c|}{$\begin{array}{l}\text { Bahan dan } \\
\text { kondisi pormukzan }\end{array}$} & \multirow{2}{*}{$\begin{array}{c}x \\
\text { penyerapan } \\
25.55 \\
50 \\
70.80 \\
50.60 \\
65.75 \\
85.95 \\
20.30 \\
10.20\end{array}$} & \multirow{2}{*}{\multicolumn{2}{|c|}{ 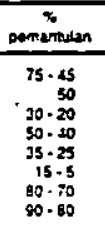 }} \\
\hline Ca & 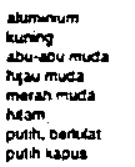 & & & \\
\hline $\begin{array}{l}\text { Semen } \\
\text { asbol }\end{array}$ & $\begin{array}{l}\text { ban stau paeth, } \\
\text { clate } \\
\text { lame }\end{array}$ & $\begin{array}{l}40.60 \\
80.95 \\
70.05\end{array}$ & $\begin{array}{r}60.40 \\
20.5 \\
30.15\end{array}$ & ! \\
\hline 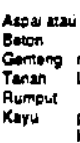 & $\begin{array}{l}\text { i botmen tod } \\
\text { moran } \\
\text { bodeng } \\
\text { pinus atau baru } \\
\text { hayu horas }\end{array}$ & $\begin{array}{c}65 \cdot 95 \\
60-70 \\
60-75 \\
70-95 \\
.60 \\
40 \cdot 60 \\
85\end{array}$ & $\begin{array}{r}15 \cdot-5 \\
40 \cdot 30 \\
40 \cdot 35 \\
30 \cdot 15 \\
20 \\
60 \cdot 40 \\
15\end{array}$ & \\
\hline $\begin{array}{l}\text { Kalang } \\
\text { tumbega } \\
\text { Warmer } \\
\text { Pasn } \\
\text { Sinte } \\
\text { Butu }\end{array}$ & 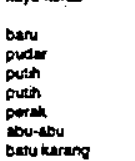 & $\begin{array}{r}25-30 \\
65 \\
20-50 \\
40 \\
70 \cdot 90 \\
75-90 \\
80-45\end{array}$ & $\begin{array}{r}75-70 \\
35 \\
60.50 \\
80 \\
30.10 \\
25.10 \\
20.15\end{array}$ & \\
\hline
\end{tabular}

\section{Bentuk dari Energi Matahari}

Radiasi sinar matahari yang diserap oleh substansi akan dirubah menjadi energi 
thernal atau panas. Kondisi ini juga menuntut bangunan untuk tidak hanya mensikapi energi matahari dari kepentingan pencahayaan tapi juga kepentingan penghawaan.

\section{Cahaya}

Bagaimańa ruang dan atau bangunan mensikapi energi matahari dalam bentuk cahaya tentunya didasari prinsip-prinsip karakteristik cahaya.

2. Energi kimiawi

Seperti diketahui bahwa di dalam radiasi matahari terdiri dari berbagai spektrum yang masing-masing mempunyai sifat khusus.

Panjang gelombang dari spektrum yang ada dalam sinar matahari pagi berpotensi terhadap proses pembunuhan bakteri yang merugikan kesehatan.

Panjang gelombang dari spektrùm yang ada dalam sinar matahari sore berpotensi terhadap pemanasan dalam nuang.

\section{Energi panas}

Beberapa karakteristik dari energi panas menurut Edward Mazria sebagai berikut :

1. Proses transferenergi panasmelalui tiga gejala:
a. konduksi
b. konveksi
c. radiasi

2. Jumlah energi panas yang dipancarkan tergantung dari :
a. temperatur permukaan yang meradiasi
b. kualitas emisitas permukaan

3. kapasitas permukaan memancarkan panas lebih tergantung dari kepadatan dankomposisi permukaandari padajenis warna.

4. secaraumum permukaanmengkilat akan lebih berpotensi dalam memantulkan radiasi panas.

5. berapa besar energi panas yang akan disimpan dan dipancarkan kembali akan tergantung dari karakteristik dari material yaitu :

(1) kapasitas suatu substansi untuk menyimpan panas disebut specific heat dengan satuan Btu's, yaitu besamya panas yang_dapat dipegang oleh satu ponds material/substansi ketika terjadi penambahan panas satu derajat Fahrenheid.

(2) sifat konduksi dari material. Untuk lebih jelas dapat dicermati tabel - Specific Heat dan Kapasitas panas dari berbagai substansi sebagai berikut :

Tabel 3: Kolor jenis dan Kapasitas Pañas dari berbagai Substansi

\begin{tabular}{|c|c|c|c|}
\hline S_ostance & 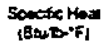 & $\begin{array}{l}\text { Densoy } \\
\text { (Descou in) }\end{array}$ & 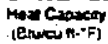 \\
\hline 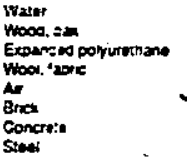 & $\begin{array}{l}1.0 \\
0.57 \\
0.30 \\
0.32 \\
0.24 \\
0.20 \\
0.156 \\
0.12\end{array}$ & $\begin{array}{l}62 . \\
47 \\
1.5 \\
6.9 \\
0.075 \\
123 \\
125 \\
489\end{array}$ & $\begin{array}{l}62.4 \\
26.8 \\
0.57 \\
22 \\
0.018 \\
25 \\
22 \\
59\end{array}$ \\
\hline
\end{tabular}

Sumber : Edward Mazria, 1979.

Beberapa , Pendekatan dalam Perumahan Sederhana mensikapi sinar matahari

Dalam buku The Passive Solar Energy Book, Edward Mazria juga mengutarakan beberapa konsep tentang Design Pattern. Di mana di dalamnya dikatakan untuk dapat mensikapi energi matahari maka ada beberapa tahap dan rekomendasi sebagai berikut :

Tahap skala makro : 
(1) lokasi bangunan

(2) bentuk bangunan

(3) orientasi bangunan

Tahap skala mikro :

(1) isolasi yang dapat digerakkan

(2) jendela matahari

\section{Lokasi Bangunan}

Dalam menentukan lokasi bangunan maka akan dicari area yang paling banyak sinar matahari pada 'Sun Time', yaitu kira-kira pada jam-jam sembilan pagi sampai dengan jam lima belas. Untuk kondisi di Indonesia yang terletak pada daerah katülistiwa maka jumlah perbedaan sinnar yang diterima pada . setiap musimnya tidak begitu besar. Lain halnya dengan perumáhan-perumahan di tempat di manaterdapatempatmusim. Dalam menentukan lokasi bangunan dipikirkan agar bangunan terbebas dari bayangan dari bangunan yang àkan dibuat dimasa mendatang. Rekomendasi ini sulit untuk bisa dilaksanakan pada perumahan sederhana. Karena gejala yang banyak muncul adalah begitu sebuah rumah di lingkungan perumahan terencana dibeli oleh seorang maka tak seberapa lama kemudian akan segera direnovasi. Di mana sisa luasan lahan yang mungkin dikembangkan sangat terbatas dan tipe susunan rumah yang banyak dipilih pada perumahan sederhana jarang memakai tipe detach. Sementara sistem manajemen kendali pengembangan sesudah akan jual beli/ akad kredit belum menjangkau untuk pengendalian renovasi rumah. Hal serupa akan terjadi pula pada tipe rumah inti. Sehingga dirasa perlu suatu manajemen kendali terhadap pengembangan rumah khususnya pada perumahan terencana.

2. Bentuk Dinding dan Orientasi

Bentuk bujur sangkar adalah bentuk yang tidak efisien dimanapun bangunan itu ditempatkan. Sedangkan bentuk memanjang sepanjang arah Utara Selatan adalah komposisi bentuk dan orientasi yang optimum.

Gambar 5 : Bentuk Empat persegi panjang pada posisi Utara Selatan.
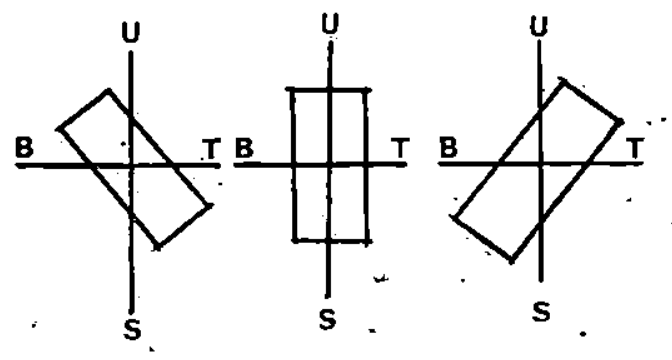

3. Sisi utara

Perhatian khusus padä sisi Utara tidak begitu berlaku pada perumahan di Indonesiakarena letak Indonesia yang berada di daerah Katulistiwa.

4. Lokasi penempatan dari ruang dalam Selain mencari zone yang memungkinkan menerima sinar matahari banyak, maka harus memperhatikan juga potensi energi kimiawi dari sinar matahari.Posisi dimana sinarmatahari pagi masukadalah posisi yang lebih baik ditinjau dari segi kesehatan. Ruang-ruang dimana penghuni tinggal lama seperti ruang tidur. living room, ruang kerja serta ruang yạng membutuhkan kondisi penyehatan khuisus seperti dapur dan 
sebagainya akan lebih baik ditempatkan di zone sebelah Timur.

5. Mempertahankan jalan masuk

Antara ruang luardan ruang dalam akan terjadi perbedaan intensitas yang jauh sehingga akan memberikan kondisi/ performance "fisiologis yang kontras sehingga akan menimbulkan ketidaknyamanan dari tujuan fisiologis.

Sehubungan dengan hal tersebut maka harus diberikan ruang perantara pada entrance berupa teras yang beratap, atau bentuk disain lainnya dimana muncul ruang yang terbayangi.

Gambar 6 : Teras sebagai buffer antara ruang luar dan ruang dalaun

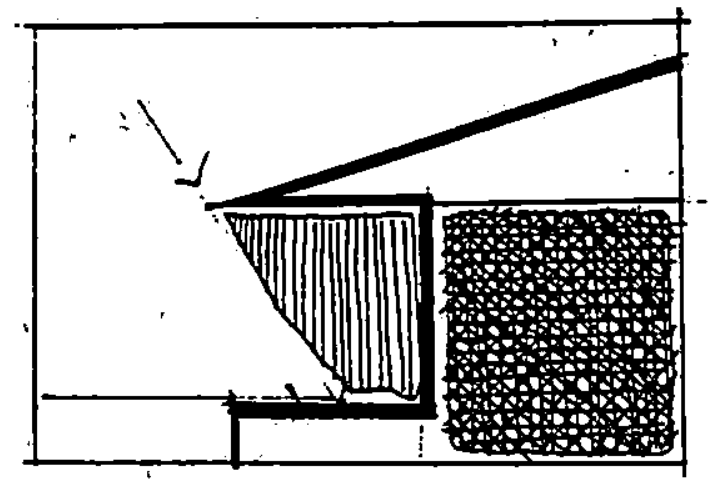

6. Lokasi jendela

Bukaan jendela utama yang baik ada di sisi Tenggara, Selatan dan Barat Daya, Timur. Untuk Barat, dan Utara harus diberikan perlakuan khusus.

Lokasi jendela selain melihat posisi terhadap potongan horizontal,jugaharus dilihat posisi vertikal. Bagaimana kondisinya dengan kedudukan teritis. Hal ini karena Indonesia ada di wilayah daerah beriklim Tropis basah dimana efek silau dari bola langit sangat kuat.
Gambar 7: Kedudukan Bukaancahaya secaravertikal dan hubungannya dengan Bola langit.
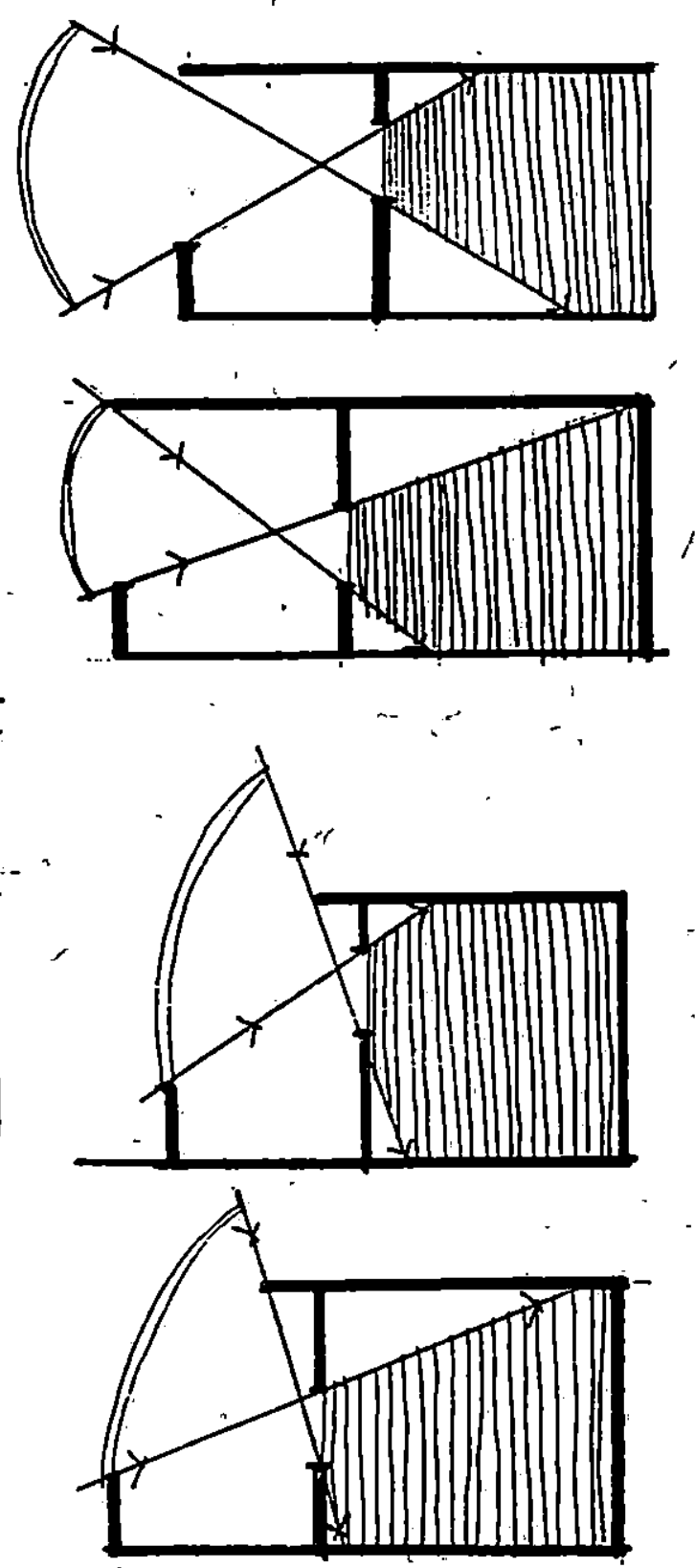

7. Pemilihan sistem pengkondisian Untuk perumahan sederhana desain tentunya sangat tergantung pada prinsip- 
prinsip pengkondisian kinerja ruang fisiologis secara alamiah.

8. Material

Menggunakan material yang mengkonsumsikan energi rendah dan paling biodegriable seperti :

(1) semen tanah

(2) batu bata

(3) batu

(4).beton

(5) air dalam wadah yang difinishing dengan baik

(6) finishing pelapis seperti : Wood, Plywood, Partical board, Gypsum board

Berikut ini material yang sebaiknya sesedikit mungkin digunakan :

(1) pahel baja

(2) aluminium

(3) plastik

(4) baja reflektor

Selain jenis material yang harus diperhatikan adalah :

(1) wama

Karena karakteristik warna akan menentukan besar pemantulan sinar matahari

(2) tekstur

\section{Kesimpulan}

1. Pengendalian terhadap solarenergi akan sulit dilakukan pada rumah-rumah di perumahan sederhana karena adanya gejala renovasi yang tidak terarah. Sehingga diperlukan mànajemen kontrol pengembangan rumahnya. Selain itu desain dibuat maksimal memenuhi kebutuhan jumlah ruang penghuni sehingga apabila terjadi pengembangan diharapkan tidak menambah besar bangunan. Dengan terbatasnya lahan maka perlu evaluasi kriteria rumah perumahan sederhana sehingga dimungkinkan developer membangun dua lantai. Permasalahannya perlu ditemukan teknologi bangunan bertingkat dengan biaya rendah.

2. Pemilihan sistem kömposisi rumahrumah pada perumahan terencana yang memungkinkan pemanfaatañ tenaga surya secaraalamiah dan optimal. Sistem susunan detach adalah sistem yang di usulkan, dengan jarak antar bangunan yang tetap memenuhi syarat memanfaatkan tenaga surya secara optimal tetapi memberikan kesulitan/ ketidak-layakan bagi penghuni untuk memanfaatkannya untuk pengembangan ruangan. Sehingga disain dari awal sudah mampu mengendalikan pola pengembangan rumah oleh pemilik rumah.

Gambar 8 :

Berbagai tipe komposisi penataan rumạh dalam site.
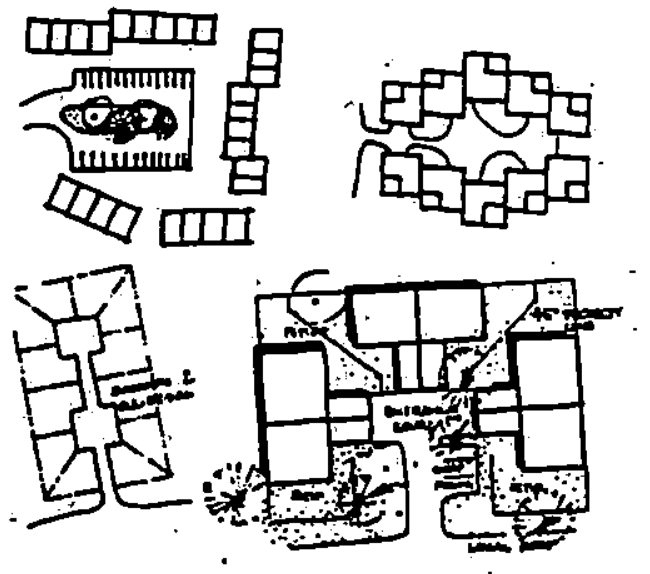


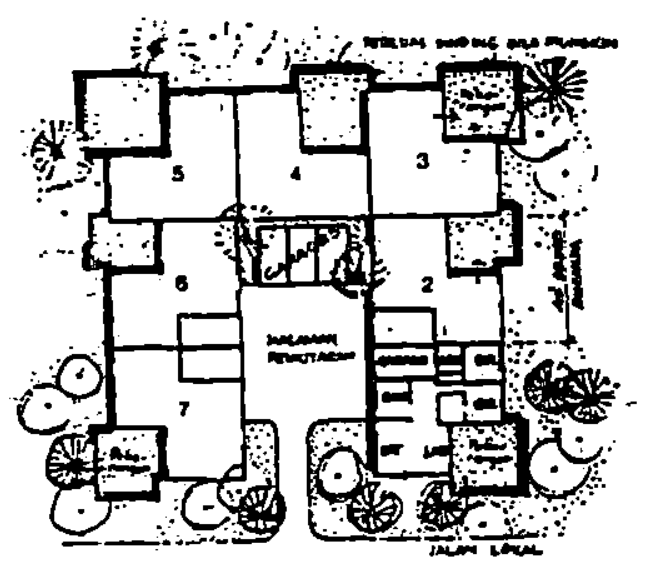

Gambar 9:berbagai komposisipenataan perumahaan dalam tapak

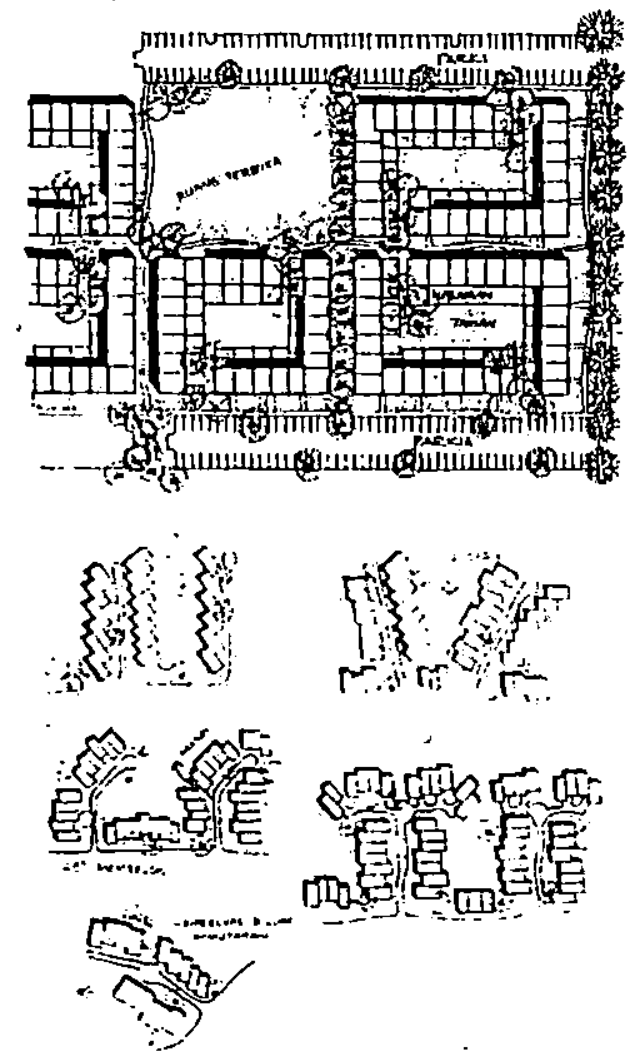

Sumber : Richard Untermnan dkk, 1984

3. Perlunya evaluasi terhadap bukaan dan kedúdukan serta lebar teritis sehingga sinar matahari dapat disikapi dengan baik. Pada kondisi keterbatasan lahan, penggunaan teknologi cahaya langit (angkasa)perlu diperkenalkan.

Gambar 10 : Pemanfaatan cahaya langit (angkasa) pada ruang dań bangunan

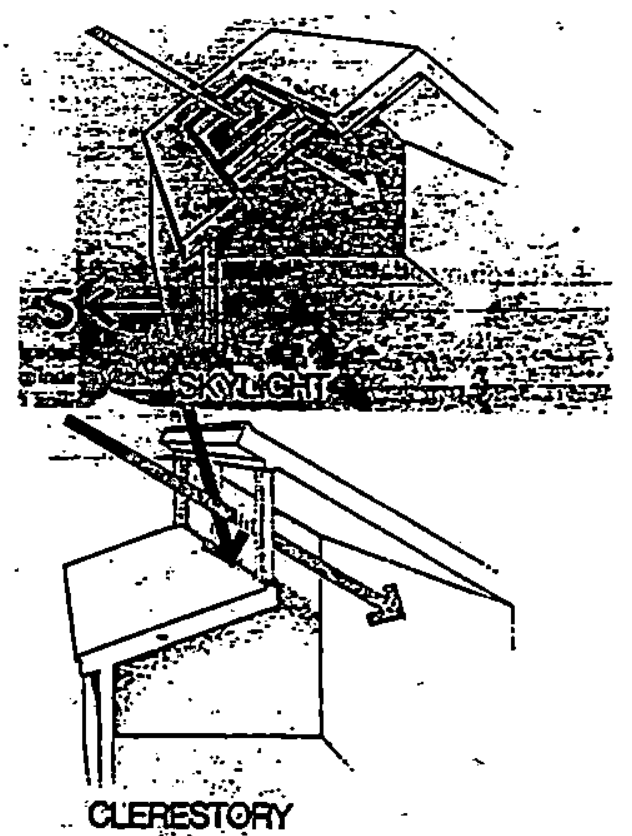

4. Perlunya pemakaian bahan material dan perlakuan bahan yang sesuai.

\section{Daftar Pustaka}

Edward Mazria, 1979, The Passive Solar Energy, Rodale Press.

Georg. Lippsmeier, 1980, Bangunan Tropis (terjemahan: Tropenbau Building in Tropics) oleh Syahmir, Nasution, Erlangga, Bandung.

Richard Untermann dkk, 1984, Perencanaan

Tapak untuk Perumahan (terjemahan : Side Planning for Cluster Housing). Intermatra; Bandung.

Siswono Yudohusodo dkk, 1991, Rumah untuk Seluruh Rakyat, Inkopal, Barakerta. 